public (the principal role of the GDC) would be enhanced by having nurses who can accurately chart.

C. Marks

By email

DOI: $10.1038 /$ sj.bdj.2012.845

\section{SHAMEFUL SITUATION}

Sir, the account Doubly impossible from Gillian Greenwood (BDJ 2012; 213: 146-147) almost beggars belief. How can it be logical that this sort of patient management is being seen as appropriate in the twenty-first century? It is the antithesis of holistic care.

I have long considered it outrageous that the mouth and its environs and any aspect of oral health care is not treated like the rest of the person and attracts a financial penalty to the NHS patient. The sky it seems is the veritable limit for anywhere else in the body!

Why, oh why, did we ever break loose from the medics and become a separate profession rather than a defined speciality within medicine? We have never fared so badly. Put the mouth back in the body? Well it may be a little too late for that, certainly for the patient groups described here. A shameful situation.

K. Marshall, Llansteffan DOI: 10.1038/sj.bdj.2012.846

\section{MORE PRACTICABLE}

Sir, we write further to the paper by S. Koshal (BDJ 2012; 213: 73-76). We agree on the importance of compulsory and thorough induction training of all DF2/ DF3 maxillofacial surgery trainees/ SHOs. Our induction process this year involved a one-week crossover period between the previous DFY2/SHOs and the new cohort. This allowed all the on-call services to be provided safely whilst the induction went ahead and also allowed opportunities for (paid) shadowing of the on-call SHO. Based upon the guide of Bridging the gap by Stark and Mitchell, the induction comprised four full days of training incorporating generic Trust induction, and local inductions in both maxillofacial surgery and ear nose and throat. Six clinical skill stations were used covering medical scenarios, ATLS and various practical skills such as systematic examination and venous cannulation. These were combined with seminars and lectures based upon case scenarios, trauma and administration/ paperwork. Again a handbook was given, covering most aspects of on-call and also outpatient work.

The original Bridging the gap training was reliant on deanery funding and also upon the trainees having time off work from their vocational training (DFY1) posts. This inevitably has proven difficult, and has been met with resistance from vocational trainers for the leave required. Hence we believe that having the induction in the first week of starting is more practicable for all involved. This creates a massive burden for those secondary care trainers involved and who are already under incredible pressures from the 'target' culture within hospitals. We continue, despite these pressures, to believe this process is vital in developing trainees who are confident and able to carry out their role safely and effectively.

M. I. Suida, D. A. Mitchell, I. McHenry

Yorkshire

1. Stark P, Mitchell D A. Bridging the gap - vocational trainee to senior house officer: a new induction course. Br Dent J 2003; 194: 167-171.

DOI: 10.1038/sj.bdj.2012.847

\section{QUIESCENT IN BIRDS}

Sir, the depiction of a Harris Hawk on the front cover of the British Dental Journal (Vol. 213 No. 4) has the caption 'Birds have no teeth'. This statement should be corrected to 'The genes expressing teeth are quiescent in birds' since it is possible to experimentally induce teeth in chicks. ${ }^{1}$ The expression 'Rare as hens' teeth' is justified by the rarity of their appearance. ${ }^{2}$

\section{G. H. Sperber, Canada}

1. Kollar E J, Fisher L. Tooth induction in chick epithelium: expression of quiescent genes for enamel synthesis. Science 1980:207: 993-995.

2. Sire J-Y, Delgado S C, Girondot M. Hen's teeth with enamel cap: from dream to impossibility. BMCEvol Biol 2008; 8: 246.

DOI: $10.1038 /$ sj.bdj.2012.848

The $B D J$ website now includes a facility enabling readers to immediately comment on letters. All comments must comply with the nature.com Terms and Conditions and Community Guidelines visit the $B D J$ website to find out more and to post your comment now. 